\title{
PROSPECTIVE OF MACEDONIA FOR TREATMENT AND RECYCLING OF TIRE WASTE WITH PIROLITIC PROCES
}

\section{PERSPEKTIVA MAKEDONIJE ZA TRETMAN I RECIKLAŽU OTPADNIH GUMA PIROLITIČKIM PROCESOM}

\author{
Victor Sarafov $^{1}$, Zoran Despodov ${ }^{1}$
}

Received: April 16, 2017

Accepted: May 12, 2017

\begin{abstract}
The automotive industry is one of the ever-developing branches of modern society and therefore collecting and recycling of old tires must not be ignored. It must be taken into consideration that tire waste is decomposing at an extremely low pace under the influence of climate factors, that waste from used tires not only is covering large areas, but there is also a possibility of spontaneous fire that is usually long-lasting and emits gasses that have negative effect on human health. Tires are made of complex polymeric materials and contain chemical additives. When burning tires on an open field highly toxic and cancerous organic compounds are being released (biphenyl, anthracene, fluoranthene and other toxins). Pyrolysis is a process that offers sustainable management of this type of waste which in continuation is to be explained in detail.
\end{abstract}

Keywords: Pyrolysis, tires, waste

\begin{abstract}
Apstrakt: Auto industrija je jedna od grana industrije koja se stalno razvija i iz tog razloga sakupljanje i reciklaža starih gume ne sme biti ignorisana. Otpadne gume se razlažu veoma sporo pod uticajem atmosferskih faktora, zauzimaju velike površine terena, stvaraju rizik za dugotrajne požare prilikom kojih se emituje ogromna količina gasova štetnih po zdravlje ljudi. Gume se prave od kompleksnih polimernih materijala i sadrže aditive. Prilikom sagorevanja na otvorenom prostoru oslobađaju se otrovne i kancerogene materije (bifenil, antracen flouranten i druge otrovne materije). Piroliza je proces koji nudi održivo upravljanje ovakvim otpadom i detaljno će biti objašnjen.
\end{abstract}

Ključne reči: Piroloiza, gume, otpad

\section{INTRODUCTION}

The system of waste management in the country and the situation in this region can be defined as ineffective with an array of technically, economically and unsustainable and organizational shortcomings, which are producing a negative impact on both the environment and indirectly on human health. Improper management of the solid waste results in increased costs for storage and also it irrationally takes up large areas.

\footnotetext{
${ }^{1}$ Faculty of Natural and Technical Sciences, University Goce Delčev - Štip emails: sarex06@yahoo.com; zoran.despodov@ugd.edu.m
} 
The reasons for this situation are many and complex, so from this point, the solution is not simple. Main drawback of the system of waste management which is largely behind the standards that are applied in developed countries, especially during the transitional period of the country. As one of the measures for sustainable management of solid waste is exactly correct choice of system for recycling of solid waste by pyrolysis process to further improve the management of all solid waste (Pingali 2005; Mainord 1994). Pyrolysis plant shown in Figure 1 is installed in the town of Stip, Macedonia.

\section{TECHNOLOGY OF THE PYROLYTIC PROCESS}

Pyrolysis is a process of thermal treatment, which is performed in the absence of oxygen in a closed system means. Research for pyrolysis on composite materials has shown that the best results are obtained at a temperature of $400{ }^{\circ} \mathrm{C}$ to $500^{\circ} \mathrm{C}$ where it comes to decomposition of the material to mainly four components: pyrolytic oil, solid carbon part or otherwise called carbon black, metal part, high calorie gas which mostly presents methane. In the process of thermal decomposition of the waste rubber in the absence of oxygen:-30-40\% is oil, about $25-40 \%$ carbon part, $10-15 \%$ metal and $15-25 \%$ methane and $5 \%$ loss during the process in the form of heavy oil direct. These parameters and variables depends on the type of waste tires and their quality. The best results are obtained from quality tires that have a higher percentage of rubber ingredients inside and a smaller amount of oil extraction in case of waste tires with a greater amount of plastic components. The main production of rubber tires is comprised of mixing the following components: styrene-butadiene rubber, carbon, zinc oxide, stearic acid, process accelerator and process oil. The mixing is an operation of bringing together all the ingredients needed to mix a series of rubber compounds. When the mixture is homogenized it is poured into molds in in which is installed steel part and with cooling the rubber product is molded. Each element has a different mix of ingredients in accordance with the properties required for that component and from this structure of the tire later in the process, the quality of the obtained products and their quantity will depend.

In the plant for recycling waste tires, the process of pyrolysis takes place in a closed loop in the plant consisting of 14 parts, which include the following components:

1. Heating system or so called reactor is essentially a boiler steel in a cylindrical shape, lying in a horizontal position, with insulating sheath and transmission rotation system. The rotation process includes an electric engine, which provides linear axis rotation of the reactor through the gear, thus homogenizing the raw material that ensures continuous operation of the process and good quality of the products 
2. Cooling system: A cooling pool with tubular heat exchanger (cooling tower). The system is in "S" shape and a condensing surface to $42 \mathrm{~m}^{2}$. The cooling is hapenning quickly using pipes;

3. The capacitor tower is with vertically mounted capacitors which can be added based on the customer requirements for product liquid (oil) that is stored in the tank.

4. The tank for collection of product oil which is produced in most estimates, is metallic, with a capacity of 100 tons set near the two lines in the plant where the pump-will be transformed into tanker which transports to the client. Filling a tank is gravitational and automatized of the two pyrolysis lines, the oil product which through a system of pipes with increased temperature is easily transported to the tank;

5. The separator of the produced heavy oil, which will be produced about $4 \%$ of the total amount-produced and its return to the pyrolysis reactor to re-use. This section oil is stored temporarily in a separate metal tank where a pump is injected into the reactor;

6. Separator tar and his reinstatement in the process of pyrolysis in the next batch;

7. System for recycling of waste gas that will be used as fuel, which is achieved not only to protect the environment but also saving energy;

8. System for obtaining solid product (carbon-carbon and metal) to be used as secondary raw material in other industries.

Technological process of installation for the processing of old tires by pyrolysis is presented by schematics in Figure 1. Table 1 presents a list of products of pyrolytic process and possible use of those.

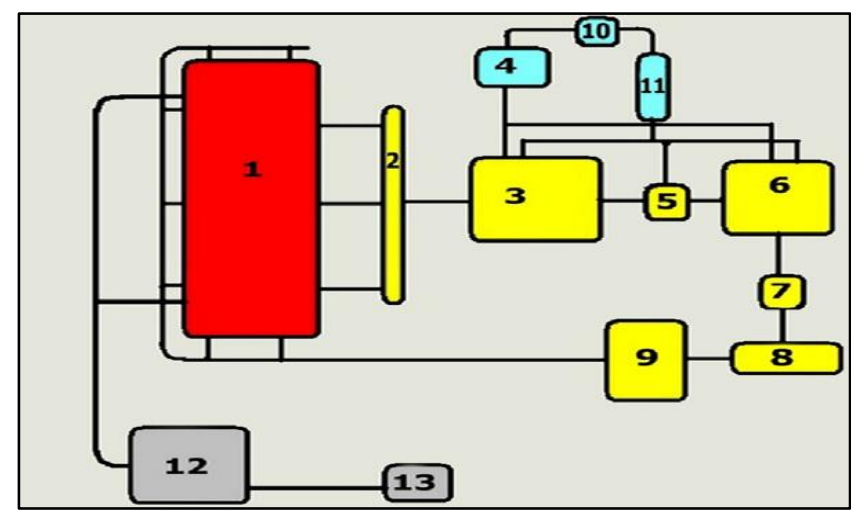

Figure 1 Pyrolysis plant 


\section{Plant equipment:}

1. Reactor (works in a vacuum, initially heated with firewood, and then obtained gases from the process); 2. Collector; 3. Catalyst; 4. Cooling the fuel obtained; 5. Systems of connection; 6. System for purification; 7. Separator; 8. Fan gases; 9. Receiver; 10. circulation system; 11. pyrolysis oil to the tank; 12. System heating 13 . Outlet gases.

Table 1 Properties and possible use of products from pyrolytic

\begin{tabular}{|c|c|}
\hline Appearance and properties & Possible applications \\
\hline \multicolumn{2}{|r|}{ Pyrolyzed oil (oil) } \\
\hline $\begin{array}{l}\text { - A dark, oily liquid with a } \\
\text { characteristic smell of diesel and } \\
\text { oil. } \\
\text { partially soluble in water (up to } \\
\text { 20\%). } \\
\text { - Flash Point (not lower than } 68^{\circ} \\
\text { C). } \\
\text { - Energy equivalent of } 42 \mathrm{MJ} / \mathrm{kg}\end{array}$ & $\begin{array}{l}\text { - It can be burned directly as a liquid fuel (substitute for } \\
\text { oil burning) for: boilers, water heaters, generators for } \\
\text { hot water / hot air or added other petroleum products, } \\
\text { power generators and diesel pumps (mixed with } 50 \% \\
\text { diesel) } \\
\text { - It can be distilled to obtain various petroleum products } \\
\text { (gasoline, diesel fuel, oil, resin, etc.). } \\
\text { - It can be used as an add-fired power plants as a } \\
\text { supplement with which the low calorie coal is sprayed } \\
\text { prior to its burning as a substitute for fuel oil. }\end{array}$ \\
\hline \multicolumn{2}{|c|}{ Pyrolytic carbon (solid carbon residue - Carbon Black) } \\
\hline $\begin{array}{l}\text { The main grain size is } 0,5-3 \mathrm{~cm} \text {, } \\
\text { with individual pieces of 6-9 cm. } \\
\text { Color - black with a gray tint. } \\
\text { - Structure - porous. } \\
\text { Composition: Carbon C }=71 \% \text {, } \\
\text { sulfur } \mathrm{S}=2,8 \% \text { and a lower } \\
\text { percentage of ash and moisture. }\end{array}$ & $\begin{array}{l}\text { - It is used as a solid fuel, } \\
\text { - It can be used for the production of modified liquid } \\
\text { fuels } \\
\text { - As an absorber and a replacement of active coal, (has } \\
\text { similar properties as the active coal in terms of } \\
\text { efficiency for the adsorption of organic compounds). } \\
\text { It can be used to purify the water (dissolved organic } \\
\text { and toxic compounds, dechlorization, treatment of } \\
\text { drinking water, swimming pools, etc.) and for air } \\
\text { purification (removal of volatile organic and } \\
\text { inorganic substances, recovery of solvents, } \\
\text { desulphurization of gas, etc.) } \\
\text { - As filler in the production of new rubber products. } \\
\text { - As an ingredient used in these industries: } \\
\text { - Production of cartridges for printers. } \\
\text { - Coating of electrical cables } \\
\text { - Conveyor belts } \\
\text { - Black nylon bags } \\
\text { - Allowance for rubber } \\
\text { - Car spare parts } \\
\text { - Thermal insulation } \\
\text { - Black colorant in rubber materials } \\
\text { - Hoses and plastic pipes } \\
\text { - Industrial Rubber Products } \\
\text { - Fire-fighting equipment } \\
\text { - Cigarette filters } \\
\text { - The food industry } \\
\text { - Batteries, fuel cells, used in nuclear power plants as a } \\
\text { substitute for fuel oil. }\end{array}$ \\
\hline
\end{tabular}


Table 1 - Continued Properties and possible use of products from pyrolytic

\begin{tabular}{|c|c|}
\hline \multicolumn{2}{|r|}{ Pyrolysis gas } \\
\hline $\begin{array}{l}\text { - } \text { - Colorless, the smell of soot. } \\
\text { - } \quad \text { humidity of } 20 \% \text {. } \\
\text { - } \quad \text { it can burn when heated to } \\
\text { temperatures above } 110^{\circ} \mathrm{C} \text {. } \\
\text { - } \quad \text { - high heating power }(35.5 \mathrm{MJ} / \\
\left.\mathrm{Nm}^{3}\right) \\
\text { - } \quad \text { Composition: mainly hydrogen, } \\
\text { methane and other hydrocarbons } \\
\text { - It has a higher calorific value } \\
\text { than natural gas. }\end{array}$ & $\begin{array}{l}\text { - The non-condensating gases are redirected back to the } \\
\text { heating chamber and used to heat the reactor as a } \\
\text { substitute for firewood or coal. } \\
\text { - The amount of gas generated in the process is } 12 \% \text { to } \\
15 \% \text { of the total amount of recycled tires and recycling } \\
\text { system with adequate capacity of waste tires } 10 \mathrm{t} / \text { day, } \\
\text { generates } 1200-1500 \mathrm{~m}^{3} \text { gas per day }\end{array}$ \\
\hline
\end{tabular}

\subsection{The advantages of pyrolysis as environmentally most suitable process}

\section{Impacts on the landscape}

Visual aspects related to the construction of the plant is not an essential aspect of its acceptability to the local population and it is likely that the majority of the local community considers the visual impact acceptable.

\section{Air Pollution}

The pyrolysis process largely takes place in the closed environment of the reactor and in the distillation part of the installed plant where emissions are not expected into the air from these processes.

Fugitive emissions of volatile organic compounds (VOC), may arise from certain components of the plant, such as tanks, pumps and valves. Fugitive emissions are possible to appear during the process of extracting the produced carbon - carbon and its packaging in jumbo bags or while cleaning the soot from the reactor which appears to happen occasionally. Analyses of soot indicate that they generally should not be considered as dangerous goods.

\section{Noise and vibration}

Noise limits of the installation under its normal operating range of 39-50 dB is far lower than $70 \mathrm{~dB}$ as it is the limited value for areas of the 4th degree applicable to industrial zones.

As to the issue of vibration emission, they are reduced to negligible values which are produced by the engines used for propulsion of the reactor, the transportation of produced products and so on. The mounting equipment is protected from vibrations produced by inserting the rubber pads on the surface where it is mounted, which are amortized eventual production of vibration. Production of vibration can cause damage to the equipment itself especially where there is a lot of RPM and therefore they must be 
eliminated or if they arise, it is a defect that must be removed so as not to cause more damage to the installed equipment which means great material loss for the investor.

\section{Impacts on surface and groundwater}

The water for cooling condensers is recycled again and there is no discharge of cooling water in normal circumstances. Very small amount of slightly acidic water, which is only $0.2 \%$ of the total volume of the final produced quantity of oil is expected to be generated in the process of pyrolysis. The water will be released into the atmosphere as vapor, leaving the acid salts with other solid debris in the reactor so that no discharge of liquid effluents. A small amount of wastewater is generated from sanitary facilities in the administrative part of the plant, due to the small number of employees. The waste water will be brought in waterproof reinforced concrete septic tank, with occasional abstraction with special tanks for that purpose by the authorized entities.

\section{Impacts on soils}

The manufacturing technology of used tires into valuable raw materials and emission of harmful pollutants that would affect the quality of surface and groundwater and soil are not expected.

\section{Impacts of waste management}

The solid residue from the process of pyrolysis - coal and scrap metal, packed in suitable packaging (impregnated bags and metal containers) are taken from manufacturers to whom they become a feedstock so there is not generating waste that is not managed sustainably.

It is important to note that the implementation of the project creates conditions for reducing waste generated from old waste tires (160 103 used tires from vehicles and 1901 wastes from incineration or pyrolysis of waste: 190102 - ferrous materials removed from the residual ash, according to the List of waste), which until now ended on the utilities or dumpsites or are burned inappropriately, which pollute the environment. Pyrolysis is an environmentally acceptable alternative to deal with waste tires and turning it into valuable raw materials - oil burning pure carbon and steel wire.

With the project capacity of the plant annually from $2.200 \mathrm{t}$, it is estimated to have generated around 550 tonnes of carbon dust and 220 tons of steel wire.

Waste oils and fats and minimal amounts of metal and other non-hazardous industrial waste is being produced from the maintenance of equipment. Chemical waste, such as waste lubricating oil, paint and oil filters for maintenance of the equipment is properly collected and disposed of in accordance with the legislation in the field of waste management. Given the relatively small number of plants in the installation, it is expected the amount of chemical waste generated to be small (Martínez, 2013). 


\section{CONCLUSION}

The process of pyrolysis as an alternative solution for sustainable management of waste tires is still irreplaceable, meaning that there is no better alternative to it.

From a detailed analysis of the impact of the media on the environment is confirmed the assumption that it is an environmentally process that minor contamination carried in the air and in the process of heating the reactor with firewood or gas that is produced by the process of pyrolysis. Other influences including surface and groundwater and soil just do not suffer any impact. Impact can only suffer in a major accident or uncontrollable outpouring of derivatives obtained or kept up their selling or in case of fire, explosion or other unforeseen natural disaster.

Noise and vibration as possible contaminants in the environment are in such a negligible phenomenon that all their further analysis are pointless, especially due to the favorable location of the installation away from populated areas.

\section{REFERENCES}

PINGALI, K. C., ROCKSTRAW, D. A. and DENG, S. (2005) Silver Nanoparticles from Ultrasonic Spray Pyrolysis of Aqueous Silver Nitrate. Aerosol Science and Technology, 39(10), pp. 1010-1014.

MAINORD, K. (1994) Cleaning with Heat: Old Technology with a Bright New Future [Online] Cleaning alternatives. Available from: infohouse.p2ric.org/ref/02/01800.pdf [Accessed 04/12/2015].

MARTÍNEZ, D. et al. (2013) Waste tyre pyrolysis - A review, Renewable and Sustainable. Energy Reviews, 23, pp. 179-213. 